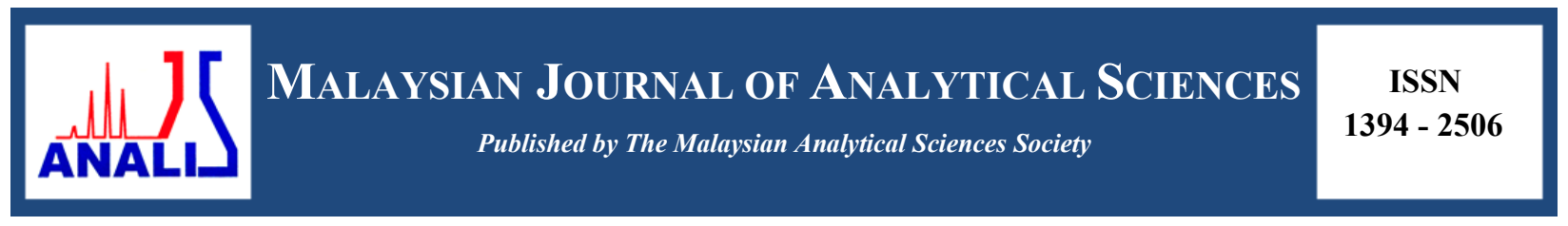

\title{
COMPARISON ON IN VITRO DEGRADATION OF POLYCAPROLACTONE AND POLYCAPROLACTONE/GELATIN NANOFIBROUS SCAFFOLD
}

\author{
(Perbandingan Degradasi In Vitro Bagi Perancah Gentian Nano Polikaprolakton dan \\ Polikaprolakton/Gelatin) \\ Lim Mim Mim ${ }^{1}$ and Naznin Sultana ${ }^{1,2 *}$ \\ ${ }^{I}$ Department of Clinical Sciences, Faculty of Biosciences and Medical Engineering \\ ${ }^{2}$ Advanced Membrane Technology Research Center \\ Universiti Teknologi Malaysia, 81310 Johor Bahru, Johor, Malaysia \\ *Corresponding author:naznin@biomedical.utm.my
}

Received: 26 August 2016; Accepted: 8 January 2017

\begin{abstract}
Tissue engineering has emerged to provide a new medical therapy in helping tissue regrowth and regeneration by employing scaffold as an artificial supporting structure for cellular growth. Many polymers have been utilized in the fabrication of these artificial scaffolds, but there is still a need to fabricate hydrophilic nanofibrous scaffold with appropriate degradation rate. In this study, polycaprolactone (PCL) and polycaprolactone/gelatin (PCL/Ge) 70:30 nanofibrous scaffolds were fabricated using electrospinning technique and compared on in vitro degradation rate to determine a more suitable scaffold for skin tissue engineering application. In vitro degradation was evaluated by morphological changes, water uptake, and chemical bonding until 12 weeks. Result shows that both PCL and PCL/Ge (70:30) nanofibrous scaffolds were degraded after 8th week. However, the degradation rate of PCL nanofibrous scaffold is slower and does not has obvious morphological changes. PCL/Ge (70:30) nanofibrous scaffold with faster degradation rate have the potential for skin tissue engineering application.
\end{abstract}

Keywords: tissue engineering, nanofibrous scaffold, in vitro degradation, polycaprolactone, polycaprolactone/gelatin

\begin{abstract}
Kejuruteraan tisu muncul untuk menyediakan terapi perubatan baru dalam membantu pertumbuhan semula tisu dengan menggunakan perancah sebagai struktur sokongan tiruan untuk pertumbuhan selular. Banyak polimer telah digunakan dalam penghasilan perancah ini, namun masih wujud permintaan terhadap penghasilan perancah gentian hidrofilik yang bersaiz nano dengan kadar degradasi yang sesuai. Dalam kajian ini, gentian perancah nano polikaprolakton (PCL) dan polikaprolakton/gelatin (PCL/Ge) 70:30 telah dihasilkan dengan teknik putaran elekron dan kadar degradasi in vitro dibandingkan untuk menentukan perancah yang lebih sesuai bagi aplikasi kejuruteraan tisu kulit. Degradasi in vitro telah dinilai melalui perubahan morfologi, penyerapan air, dan ikatan kimia kedua-dua gentian perancah nano sehingga 12 minggu. Keputusan menunjukkan kedua-dua PCL dan PCL/Ge (70:30) gentian perancah nano telah degradasi selepas minggu ke-8. Walau bagaimanapun, kadar degradasi gentian perancah nano PCL adalah lebih perlahan dan tiada perubahan morfologi yang jelas. Gentian perancah nano PCL/Ge (70:30) dengan kadar degradasi yang lebih cepat mempunyai potensi dalam bidang kejuruteraan tisu kulit.
\end{abstract}

Kata kunci: kejuruteraan tisu, perancah gentian nano, degradasi in vitro, polikaprolakton, polikaprolakton/gelatin

\section{Introduction}

Tissue engineering is an interdisciplinary field that uses life sciences and engineering principles to develop biological substitutes for example fibrous scaffold for improving, maintaining and restoring the function of tissues 


\section{Lim \& Naznin: COMPARISON ON IN VITRO DEGRADATION OF POLYCAPROLACTONE AND \\ POLYCAPROLACTONE/GELATIN NANOFIBROUS SCAFFOLD}

or organs. Skin tissue engineering has been developed recently due to the limitations of autografts and allografts such as availability of healthy autologous skin, infections, and scarring. The emergence of skin tissue engineering facilitates the treatment of patients with deep dermal injuries, deep skin burns, and skin related disorders [1]. Skin tissue engineering aims to promote the healing of wounds [2], repair, and promote the regeneration of skin tissue with reduced scarring [1] by applying fibrous scaffold on the wounds.

There are many techniques of scaffold fabrication. One of the techniques which is simple and cost effective for fibrous scaffold fabrication is electrospinning technique [3]. Electrospinning, a technique that utilises electrostatic forces to produce fibers has been emerging from 100 years ago [4]. This technique is versatile to spin a wide range of materials such as polymers, composites, and ceramics into extremely thin fibers ranging from micrometers to a few nanometers [5]. These thin fibers mimic the structural dimension of extracellular matrix (ECM) of tissues and organs [4]. Moreover, small dimension of fibers provides high surface area to volume ratio for cellular growth [4]. The product of electrospinning is called electrospun fiber or electrospun membrane or fibrous scaffold. Electrospinning technique is able to fabricate nano-sized fibrous scaffolds which mimic ECM of skin for skin tissue engineering.

To fabricate scaffold, biomaterials such as biodegradable polymers are widely used as the material of scaffold. Using biodegradable polymer as scaffold, it will provide an adequate support for cells and degrade at a rate coincide with tissue growth. Biodegradable polymers are divided into biodegradable synthetic polymers and natural polymers. In this study, biodegradable synthetic polymer, polycaprolactone (PCL) and natural polymer, gelatin (Ge) were used. Both polymers were Food and Drug Administration (FDA) approved to be safe for human body [6, 7].

Some studies observed that PCL fibrous scaffolds caused a reduction in the ability of cell attachment, migration, proliferation, and differentiation [8]. Cell affinity towards synthetic polymer is usually poorer than natural polymer. PCL has the advantages of biodegradable and biocompatibility, but it has lower hydrophilicity, slower degradation rate, and lack of surface cell-recognition sites [9]. Ge is a natural polymer derived from collagen, the main structural component of ECM of skin. It is hydrophilic and has faster degradation rate. Previous study had investigated Ge and blending of Ge with poly(L-lactic acid)-co-poly(e-caprolactone) (PLACL) for the application of skin tissue engineering [10,11]. Ge fibrous scaffold has the potential for dermo-epidermal composite skin substitute [10]. Blending of poly(L-lactic acid)-co-poly(e-caprolactone) (PLACL)/Ge is favorable for cell infiltration [11]. However, an appropriate degradation rate is also an important characteristic for skin tissue engineering application. In this study, Ge is selected to be blended with PCL to achieve a desired fibrous scaffold for the aim to increase the degradation rate. PCL and PCL/Ge (70:30) nanofibrous scaffolds were compared on in vitro degradation to choose a suitable scaffold for skin tissue engineering application.

\section{Materials and Methods}

Polymer Ge Type A in powder form ( $\sim 300 \mathrm{~g}$ Bloom) from porcine skin, PCL with molecular weight 70,000 90,000 , formic acid ( $\geq 95 \%$ ), and phosphate buffered saline (PBS, P-3813, pH 7.4) were obtained from Sigma Aldrich (St. Louis, MO). PCL and PCL/Ge with weight ratio 70:30 were dissolved in formic acid. Both solutions were electrospun to fabricate nanofibrous scaffolds by using electrospinning technique. Degradation of PCL and PCL/Ge (70:30) nanofibrous scaffolds was evaluated by morphological changes and water uptake. Nanofibrous scaffolds were sectioned into $1 \times 1 \mathrm{~cm}^{2}$, weighted, and incubated at $37^{\circ} \mathrm{C}$ in $10 \mathrm{ml}$ PBS. After 4,8 , and 12 weeks of incubation, nanofibrous scaffolds were washed with distilled water to remove residual buffer salts. Nanofibrous scaffolds were blotted dry with tissue paper to remove excess water and weighted. Water uptake of nanofibrous scaffolds was calculated using the following equation 1 [12].

$$
\text { Water Uptake }(\%)=\frac{\mathrm{W}_{\mathrm{w}}-\mathrm{W}_{\mathrm{d}}}{\mathrm{W}_{\mathrm{d}}} \times 100
$$

where $\mathrm{W}_{\mathrm{w}}$ is weight of scaffold after incubation, $\mathrm{W}_{\mathrm{d}}$ is weight of scaffold before incubation.

This process was repeated for three times for each time point. The average and standard deviation of water uptake was plotted against degradation time. Nanofibrous scaffolds were dried at room temperature until a constant weight 
had achieved and coated with gold for the preparation to be viewed under field emission scanning electron microscope (FESEM). Morphological changes of the fibers after degradation for 8 and 12 weeks were determined by FESEM images.

Chemical bonding analysis of both PCL and PCL/Ge nanofibrous scaffolds was performed by using an attenuated total reflectance (ATR) spectroscopy (Perkin-Elmer Series, USA Modal) in the range of $4000-400 \mathrm{~cm}^{-1}$.

\section{Results and Discussion}

PCL and PCL/Ge (70:30) scaffolds were fabricated using electrospinning technique by using formic acid as solvent. $14 \% \mathrm{w} / \mathrm{v}$ of PCL and PCL/Ge (70:30) in formic acid formed fibrous scaffold with nanosized diameter. Previous study had reported that the average fiber diameter of PCL and PCL/Ge (70:30) fibrous scaffolds were $88.02 \pm 27.83$ $\mathrm{nm}$ and $155.60 \pm 41.13 \mathrm{~nm}$ [13]. The contact angle of as-fabricated PCL was $112.30 \pm 8.14$ and $43.83 \pm 0.06$ for $\mathrm{PCL} / \mathrm{Ge}$. Both nanofibrous scaffolds were compared on in vitro degradation. Biodegradable scaffolds are usually degraded and replaced by new tissue. Ideally, the rate of degradation should match the rate of tissue regeneration or tissue growth in vitro and in vivo $[9,14,15]$. In this study, PCL and PCL/Ge (70:30) nanofibrous scaffolds were incubated in $\mathrm{PBS}$ at $37^{\circ} \mathrm{C}$ for 12 weeks.

Figure 1 illustrates the morphological changes of PCL and PCL/Ge (70:30) nanofibrous scaffolds before incubation and after 8 and 12 weeks of incubation. From the FESEM images, there was no broken fiber was observed. The fiber diameters of PCL and PCL/Ge increased after absorbing water at different degradation period which is referred as "swelling".
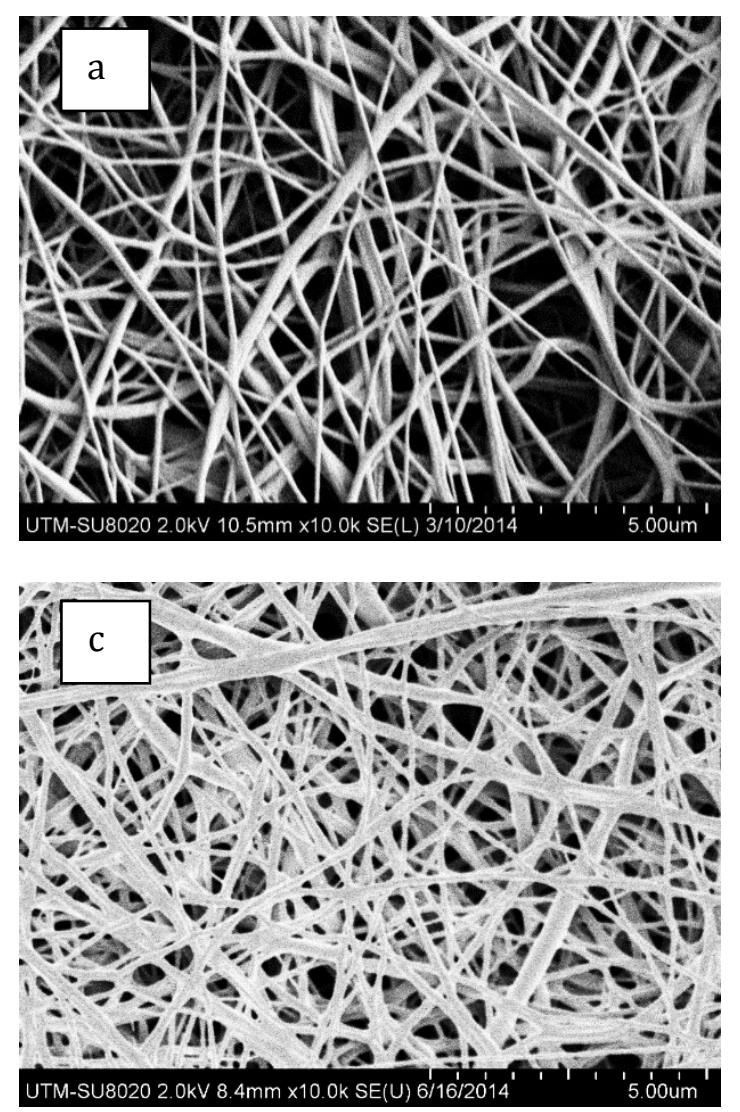
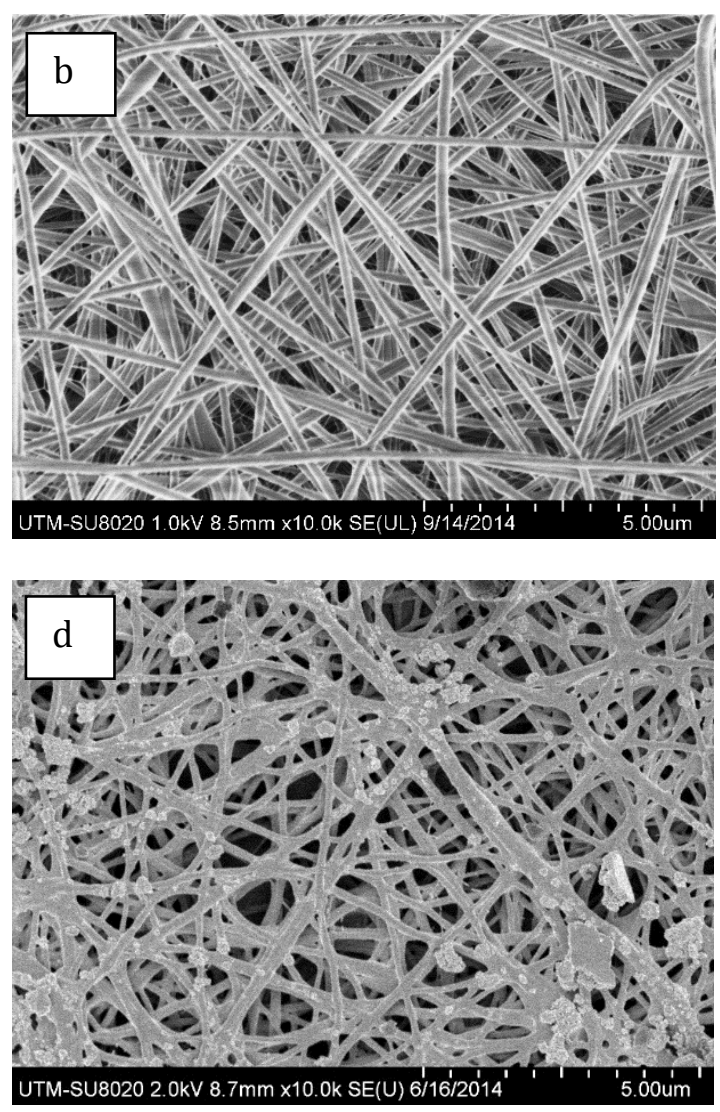

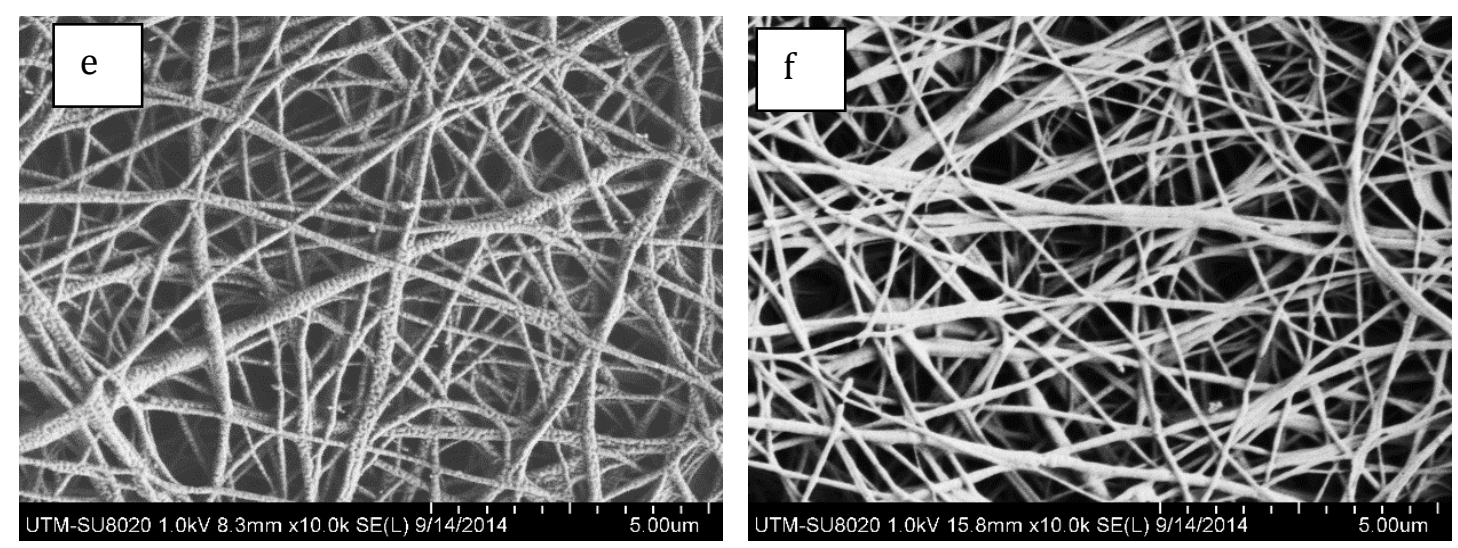

Figure 1. FESEM images of PCL (left) and PCL/Ge (70:30) (right) nanofibrous scaffolds for in vitro degradation $(a, b)$ before degradation, (c, d) after 8 weeks, $(e, f)$ after 12 weeks

Water uptake percentage of PCL and PCL/Ge (70:30) nanofibrous scaffold was also studied for 4, 8, and 12 weeks to evaluate the rate of degradation. Figure 2 shows the percentage of water uptake.

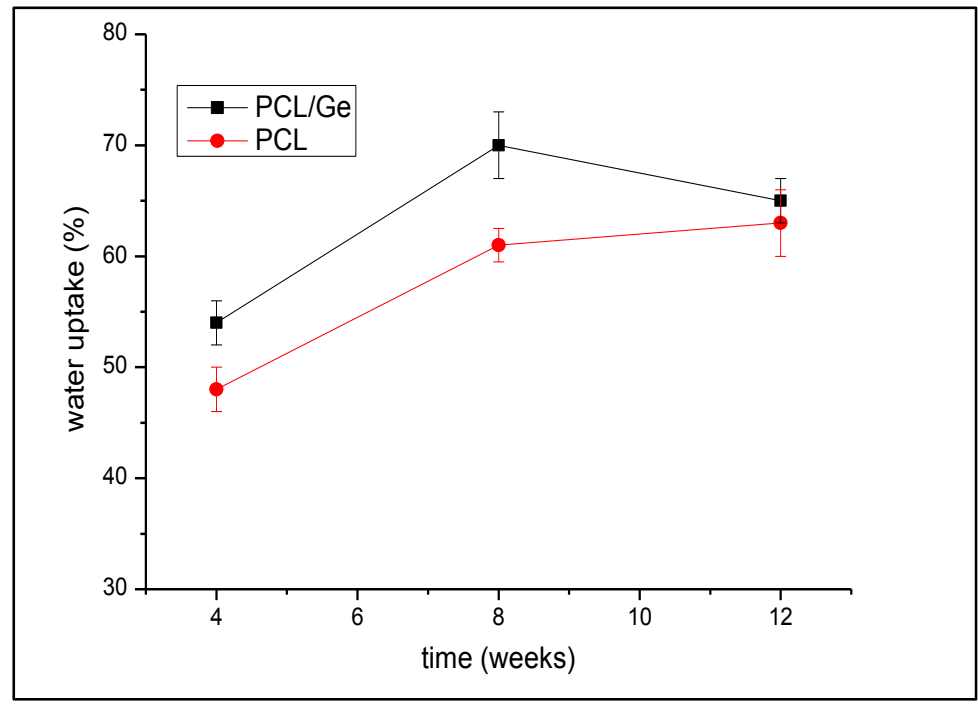

Figure 2. Water uptake percentage of PCL and PCL/Ge (70:30) nanofibrous scaffolds after degradation for 4, 8 , and 12 weeks

With increasing time, water uptake percentage of PCL nanofibrous scaffold was increasing, but water uptake percentage of $\mathrm{PCL} / \mathrm{Ge}$ (70:30) nanofibrous scaffold decreased at week 8. In overall, percentage of water uptake of PCL/Ge nanofibrous scaffold was higher than PCL nanofibrous scaffold due to the presence of an amide bond. Amide bond of Ge presence in PCL/Ge scaffold is able to form hydrogen bonds with water molecules. Hence, $\mathrm{PCL} / \mathrm{Ge}$ nanofibrous scaffold is hydrophilic and takes up more water. However, from the result, percentage of water uptake decreased at week 8 as nanofibrous scaffolds were started to degrade. Degradation of amide bond decreases its ability to form hydrogen bonds with water molecules. Hence, percentage of water uptake was decreased. 
Chemical structure of both PCL and PCL/Ge (70:30) nanofibrous scaffolds are investigated using ATR. Figure 3 shows the ATR spectra of PCL and PCL/Ge nanofibrous scaffolds before and after degradation.
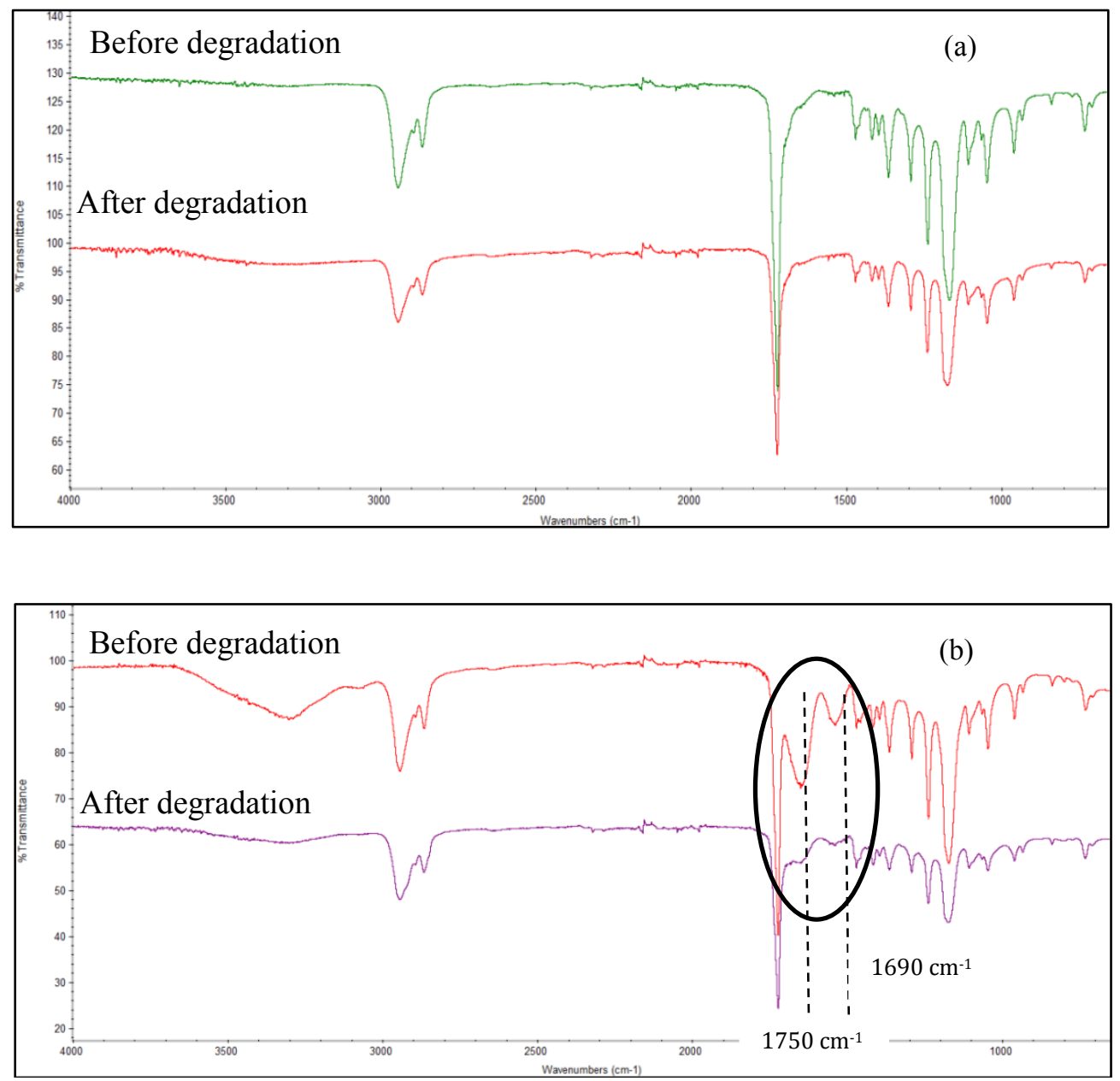

Figure 3. Chemical structure analysis of nanofibrous scaffolds before and after degradation for 8 weeks (a) PCL and (b) PCL/Ge

PCL is a polyester containing ester $(\mathrm{C}=\mathrm{O}-\mathrm{O})$ groups and cyclic alkyl groups. It can be observed in Figure 3 (a) that there are three prominent absorption peaks displayed in both polycaprolactone (PCL) spectra before and after degradation. Absorption band at around 2900 and $2800 \mathrm{~cm}^{-1}$ are attributed to asymmetric and symmetric $\mathrm{sp}^{3} \mathrm{C}-\mathrm{H}$ stretching, $1730-1750 \mathrm{~cm}^{-1}$ is assigned to $\mathrm{C}=\mathrm{O}-\mathrm{O}$, and $1150 \mathrm{~cm}^{-1}$ is indicated the presence of $\mathrm{C}-\mathrm{O}$ group. The difference between these two spectra is that the loss of concentration of PCL proven by decreasing of the PCL intensity in the spectrum after degradation.

In Figure 3 (b), it is clearly seen that the absorption peak of carboxylate group $\left(\mathrm{C}=\mathrm{O}-\mathrm{O}\right.$, around $\left.1730-1750 \mathrm{~cm}^{-1}\right)$, amide group $\left(\mathrm{C}=\mathrm{O}-\mathrm{N}, 1690 \mathrm{~cm}^{-1}\right)$ and carbonyl group $\left(1150 \mathrm{~cm}^{-1}\right)$ reduced after the $8^{\text {th }}$ week. It is proven that the $\mathrm{PCL} / \mathrm{Ge}$ degraded in PBS solution. Hence, the water absorption capacity was decreased due to the loss of carboxylate, amide and carbonyl groups which can form hydrogen bonding with water molecules.

Both PCL and PCL/Ge nanofibrous scaffolds were degraded after $8^{\text {th }}$ week. However, the degradation rate of PCL nanofibrous scaffold is slower and does not has obvious morphological changes. PCL has been known for its slow 


\section{Lim \& Naznin: COMPARISON ON IN VITRO DEGRADATION OF POLYCAPROLACTONE AND \\ POLYCAPROLACTONE/GELATIN NANOFIBROUS SCAFFOLD}

degradation rate which can degraded up to $3-4$ years [6]. After adding Ge, degradation rate has increased. Type of the chemical bond and water uptake are the most important factors that will influence the rate of degradation of a scaffold $[15,16]$.

\section{Conclusion}

In this study, nanofibrous scaffolds of PCL and PCL/Ge with weight ratio 70:30 were produced. The results reported in this study demonstrated that the degradation rate of PCL/Ge (70:30) nanofibrous scaffold was faster than PCL nanofibrous scaffold. PCL nanofibrous scaffold with slow degradation rate is more suitable to be used for long-term implantation and long-term drug delivery carrier while PCL/Ge (70:30) nanofibrous scaffold might have the potential to be used for skin tissue engineering application.

\section{Acknowledgement}

The authors would like to acknowledge MOHE for the GUP Tier 1 grants (Vot: 12H24) and HiCOE grant (Vot: 4J191) as well as lab facilities of Universiti Teknologi Malaysia (UTM).

\section{References}

1. Priya, S. G., Jungvid, H. and Kumar, A. (2008). Skin tissue engineering for tissue repair and regeneration. Tissue Engineering Part B: Reviews, 14(1): 105 - 118.

2. Mansbridge, J. (2008). Skin tissue engineering. Journal of Biomaterial Science, Polymer Edition, 19(8): $955-968$.

3. Zhang, Y., Ouyang, H., Lim, C. T., Ramakrishna, S. and Huang, Z. M. (2005). Electrospinning of gelatin fibers and gelatin/PCL composite fibrous scaffolds. Journal of Biomedical Materials Research Part B, 72(1): $156-165$.

4. Sill, T. J. and von Recum, H. A. (2008). Electrospinning: applications in drug delivery and tissue engineering. Biomaterials, 29(13), 1989 - 2006.

5. Goh, Y. F., Shakir, I. and Hussain, R. (2013). Electrospun fibers for tissue engineering, drug delivery, and wound dressing. Journal of Materials Science, 48(8): 3027 - 3054.

6. Gelatin Manufacturers Institute of America (2012). Gelatin Handbook. Access from Dostupné z: www. gelatingmia.com/images/GMIA_Gelatin_Manual_2012.pdf.

7. Woodruff, M. A. and Hutmacher, D. W. (2010). The return of a forgotten polymer - polycaprolactone in the $21^{\text {st }}$ century. Progress Polymer Science, 35(10), $1217-1256$.

8. Kim, C. H., Khil, M. S., Kim, H. Y., Lee, H. U. and Jahng, K. Y. (2006). An improved hydrophobicity via electrospinning for enhanced cell attachment and proliferation. Journal of Biomedical Materials Research Part $B, 78(2): 283-290$.

9. Ghasemi-Mobarakeh, L., Prabhakaran, M. P., Morshed, M., Nasr-Esfahani, M.-H. and Ramakrishna, S. (2008). Electrospun poly( $\varepsilon$-caprolactone)/gelatin nanofibrous scaffolds for nerve tissue engineering. Biomaterials, 29(34): $4532-4539$.

10. Powell, H. and Boyce, S. (2008). Fiber density of electrospun gelatin scaffolds regulates morphogenesis of dermal-epidermal skin substitutes. Journal of Biomedical Materials Research Part A, 84(4): 1078 - 1086.

11. Chandrasekaran, A. R., Venugopal, J., Sundarrajan, S. and Ramakrishna, S. (2011). Fabrication of a nanofibrous scaffold with improved bioactivity for culture of human dermal fibroblasts for skin regeneration. Biomedical Materials, 6(1): 015001.

12. Sultana, N. and Khan, T. H. (2012). In vitro degradation of PHBV scaffolds and nHA/PHBV composite scaffolds containing hydroxyapatite nanoparticles for bone tissue engineering. Journal of Nanomaterials, 2012: $1-12$.

13. Lim, M. M., Sun, T., and Sultana, N. (2015). In vitro biological evaluation of electrospun polycaprolactone/ gelatine nanofibrous scaffold for tissue engineering. Journal of Nanomaterials, 2015: 1 - 11.

14. Chang, H.-I. and Wang, Y. (2011). Cell responses to surface and architecture of tissue engineering scaffolds: In Tech Open Access Publisher: pp. $569-588$.

15. Cui, W., Li, X., Zhou, S. and Weng, J. (2008). Degradation patterns and surface wettability of electrospun fibrous mats. Polymer Degradation and Stability, 93(3): 731 - 738.

16. Sultana, N. and Kadir, M. R. A. (2011). Study of in vitro degradation of biodegradable polymer based thin films and tissue engineering scaffolds. African Journal of Biotechnology. 10(81): $18709-18715$. 